\title{
The evolution of clinical guidelines for antimicrobial photodynamic therapy of skin
}

\author{
Alison M. Mackay ${ }^{1,2,3}$ \\ Received: 13 July 2021 / Accepted: 28 December 2021 / Published online: 7 February 2022 \\ (c) The Author(s), under exclusive licence to European Photochemistry Association, European Society for Photobiology 2022
}

\begin{abstract}
Antimicrobial photodynamic therapy has become an important component in the treatment of human infection. This review considers historical guidelines, and the scientific literature to envisage what future clinical guidelines for treating skin infection might include. Antibiotic resistance, vertical and horizontal infection control strategies and a range of technologies effective in eradicating microbes without building up new resistance are described. The mechanism of action of these treatments and examples of their clinical use are also included. The research recommendations of NICE Guidelines on the dermatological manifestations of microbial infection were also reviewed to identify potential applications for PDT. The resistance of some microbes to antibiotics can be halted, or even reversed through the use of supplementary drugs, and so they are likely to persist as a treatment of infection. Conventional PDT will undoubtedly continue to be used for a range of skin conditions given existing healthcare infrastructure and a large evidence base. Daylight PDT may find broader antimicrobial applications than just Acne and Cutaneous Leishmaniasis, and Ambulatory PDT devices could become popular in regions where resources are limited or daylight exposure is not possible or inappropriate. Nanotheranostics were found to be highly relevant, and often include PDT, however, new treatments and novel applications and combinations of existing treatments will be subject to Clinical Trials.
\end{abstract}

\section{Graphical abstract}
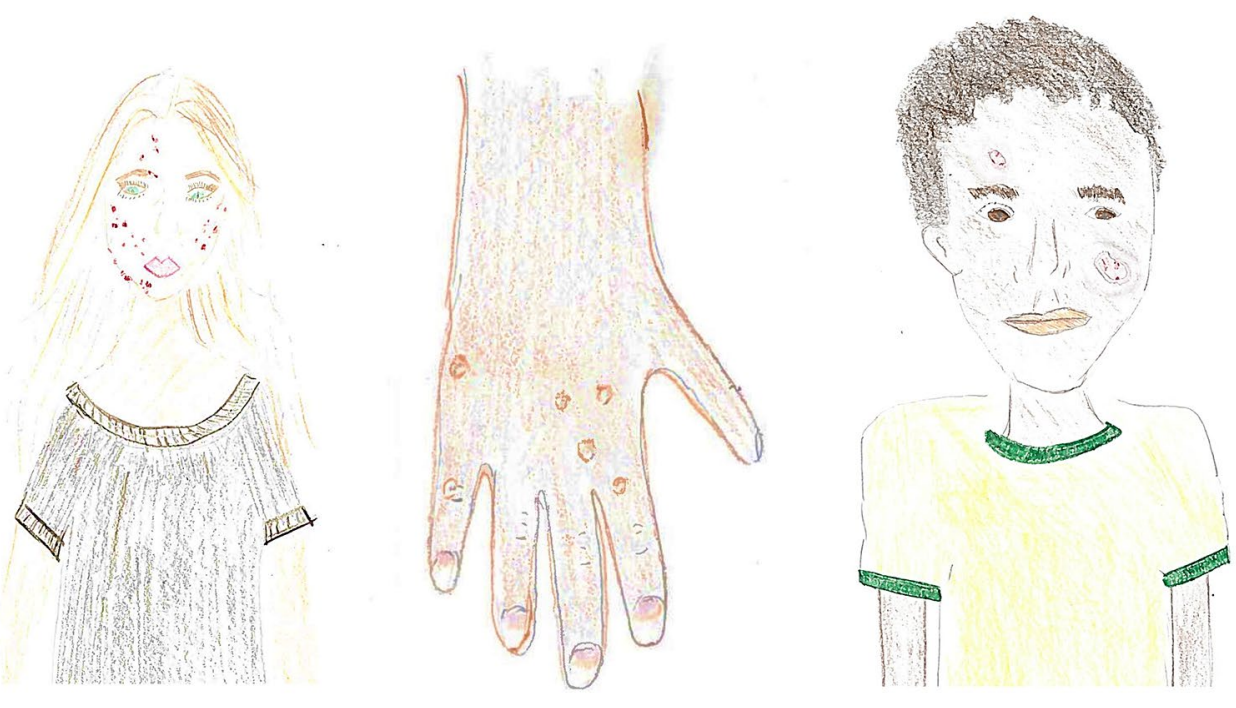

Keywords Antimicrobial $\cdot$ Clinical guideline $\cdot$ Photodynamic therapy $\cdot$ Nanotheranostics $\cdot$ Infection

Alison M. Mackay

alisonmackay@live.co.uk

Extended author information available on the last page of the article 


\section{Introduction}

The aim of this review is to describe why antimicrobial Photodynamic therapy (aPDT) has become an important component in the treatment of human infection and to discuss what future guidelines for its clinical application might include. The emergence of antibiotic resistance has been considered, as have vertical and horizontal infection control strategies [1], and a range of technologies effective in eradicating microbes without building up new resistance. The mechanism of action of these technologies is described and examples of their clinical use summarised. Finally, national and international clinical guidelines on the manifestations of microbial infection and the use of PDT have been studied, including their research recommendations. While consensus on the use of antimicrobial PDT in humans is the ultimate focus of this review, it is first acknowledged that: the methods were developed in the laboratory; [2] many of the basic science investigations were done on murine cohorts; [3] current veterinary indications for PDT are broad ranging and include bacterial infection in domestic animals [4].

Antibiotics were clinically introduced during the Second World War and the emergence of resistant strains of bacteria was described as early as 1959 [5] followed by a detailed study of the underpinning mechanisms revealing several modes of resistance. Innate immunity to specific antibiotics exists in microbes because of impenetrable cell membranes, active cell efflux, and/or the presence of certain gene alleles in specific positions on the chromosome creating a resistant phenotype [6]. These mechanisms predate the use of antibiotic drugs [6]. Extrinsic resistance is an acquired property evolving via mutation, or during experimental recombination [7], when antibiotics are used at subinhibitory concentrations causing recombination [8], or via horizontal transfer of r-genes [9].

Methods of tracing the evolution of microbial strains have been described including phylogenetic trees [10]retrospective by nature-and prospective in-vivo measurements of the natural course of the nosocomial bacterial infection becoming resistant to a series of antibiotics [11]. Nanotheranostics offers additional insights by allowing observation of microbes in-situ, [12] and during treatment.

During the Covid-19 pandemic, infection prevention and control in public places and healthcare has been enhanced [13-16] to minimise the proliferation of the virus. However, antimicrobial stewardship has diminished $[17,18]$ with the net effect likely to be a worldwide increase in microbial resistance. In their 2010 paper, Davies and Davies [19] highlight the presence of multidrug-resistant bacteria in the biosphere with consequences aggravated by civil unrest, violence, famine, natural disaster and poor hospital practices; and so the net longterm effects of Covid-19 on bacteria, and indeed other microbes, has yet to be realised. Multiple and extreme (a lack of susceptibility to four or more drugs) antibiotic resistance has necessitated the use of alternative treatment methods for microbial infection including electroporation [20]; antimicrobial peptides (AMPs) [21]; photodynamic therapy (PDT) [22]; photothermal therapy [23]; nitrous oxide (NO) releasing nanoparticles [24]; cannabidiol [25]; or combinations of therapies. Electroporation is a technique where $30-100 \mathrm{~V}$ pulses are used for a fraction of a second to create local aqueous permeable regions in between lipid membranes by destabilisation [26], however, its clinical importance have yet to be tested. Accessibility and limitations on sensitivity and specificity of PDT has been addressed by conjugation of known photosensitisers to cationic molecules, AMPs, antibodies, targeted antibiotics or nanomaterials [27-32]. Gold nanorods conjugated with antibodies or AMPs then introduced into the bloodstream and irradiated externally achieve both Photodynamic and Photothermal effects [33, 34]. Polyvalent ligand strategies optimise the yield of any exogenous agent [35] and have been used to achieve simultaneous lightcontrolled drug release, Photodynamic and Photothermal treatments. The field of nanotheranostics takes the use of nanomaterials a step further by utilising agents with luminescent properties, allowing diagnostic imaging and treatment to be achieved concurrently [36]. Transdermal Iontophoresis is a system for the controlled delivery of pharmaceuticals using small electric currents, and works particularly well for small lipophilic molecules [37]. It has previously been used to facilitate PDT [38] and allow therapy at lower anti-inflammatory drug concentrations than localised injections [39]. For the photosensitising agents of PDT, iontophoresis facilitates a much shorter incubation time before illumination [40]. Even without light, the electrical activation of silver ions (oligodynamic iontophoresis) has shown broad-spectrum antimicrobial activities against bacteria, fungi and viruses [41]. The technique uses a much smaller current than electroporation, therefore reducing the electrical hazards involved [42].

Photodynamic Therapy is immune to resistance, and has been used clinically since the 1970's to treat a range of cancers and precancerous skin lesions [43], Age-related Macular Degeneration (AMD) [44, 45], Artherosclerosis [46], Arthritis [47], Barrett's Oesophagus [48], Psoriasis [49], and Restenosis [50]. The treatment of Infectious disease using PDT is a relatively recent application that does not discriminate between strains that are and are not resistant to antibiotics $[51,52]$. PDT requires a photosensitiser or pro-drug to be applied topically, intravenously or by an expanding range of other routes including oral, intra-auricular injection and transvaginal fibre [53]. In wound infection and healing, it 
is vital that the photosensitiser is applied topically to maximally preserve vasculature to the site [54]-residual product in the proximal capillaries and arterioles following systemic delivery could lead to their destruction during illumination of a site with deeply penetrating light. On absorption of a photon, one of the photosensitisers (PS) two singlet state electrons is temporarily elevated to an excited singlet state creating fluorescence or heat on its return. Alternatively, the electron may have its spin inverted (parallel to its counterpart) creating a new excited triplet state in a process called intersystem crossing. From here, one of two things can happen: (1) The particle reacts directly with the surrounding tissue (substrate) forming a radical anion or cation which then reacts with oxygen in the air to produce reactive oxygen species (ROS); (2) All of the electron's energy is transferred to oxygen from the air forming singlet oxygen. Both these outcomes result in cell death by necrosis or apoptosis, and the specific substrate, photosensitiser and level of oxygen will influence the ratio of type 1 and 2 reactions [55].

Photosensitisers can be grouped by their chemical composition and Table 1 highlights relevant features of different groups. Protoporphyrin IX is a naturally occurring photosensitiser, whose localised production can be stimulated from the pro-drug aminivulinic acid (ALA). However, the derived hematoporphyrin Benzoporphyrin monoacid ring A (BPD$\mathrm{MA}$ ) is thought to be ten times as effective [56]. Xanthenes stand out from the table as being versatile, and when used in combination have been shown to greatly reduce biofilms of Stapphylococcus mutans at low concentrations and with short illumination times [57]. Phenothiazines appear equally versatile and their hydrophilicity allows them to conquer the rigid cell wall of funghi [58]; incidentally, where candida infection is localised to the stratum corneum, then illumination with blue light is preferable. The addition of inorganic salts potentiates microbial killing [59] in either type 1 or 2 reactions; azide and potassium iodide have been used with phenothiazines and cationic fullerenes and bromide alongside titanium dioxide nanoparticles [60]. In clinical practice this facilitates the same outcome with a smaller light fluence, further reducing the damage to healthy tissue.

Combining a bioprecursor (prodrug), coumarin and triphenlyphosphonium then incorporating them onto carbon dots allows mitochondria to be targeted and the achievement of highly localised PDT with limited damage to surrounding cells [61]. Omitting the incubation period may lend itself to specific settings and applications. Treatment of leg ulcers and wounds with methylene blue and an $810 \mathrm{~nm}$ diode laser (fluence $60 \mathrm{~J} / \mathrm{cm}^{2}$ ) did not require any incubation time and was shown to be much more successful than just using the laser; two-thirds of ulcers showed partial improvement, while $83 \%$ of split skin sites showed a very good response [62]. Similar chemical and physical parameters and a

Table 1 Photosensitisers used in antimicrobial PDT studies by a range of methods

\begin{tabular}{|c|c|c|c|c|c|}
\hline Photosensitiser & First author & Year & Type of study & Absorption & Attributes \\
\hline Porphyrins & Merchat [101] & 1996 & Animal lab & $610-630 \mathrm{~nm}$ & Cationic versions are suited to killing of bacteria \\
\hline Pthalocyanines & $\mathrm{Ng}[102]$ & 2014 & Clinical & $670-700 \mathrm{~nm}$ & $\begin{array}{l}\text { Absorbs at low energies. High production of } \\
\text { ROS and low skin toxicity in ambient light } \\
\text { support their topical use }\end{array}$ \\
\hline 5-Aminovulinic acid & Ibbotson [103] & 2002 & Clinical & $503-628 \mathrm{~nm}$ & Rapid action reduces the risk of photosensitivity \\
\hline Chlorins & De Annunzio [104] & 2019 & Clinical review & $650-660 \mathrm{~nm}$ & Has a high quantum yield of singlet oxygen \\
\hline Xanthenes & Yin [105] & 2015 & Animal lab & $532 \mathrm{~nm}$ & Kills viruses, bacteria and protozoa \\
\hline Phenothiazines & Wison and Mia [106] & 1993 & Biological lab & $625 \mathrm{~nm}, 656 \mathrm{~nm}$ & $\begin{array}{l}\text { Kills both Gram-positive and Gram-negative } \\
\text { bacteria and some funghi }\end{array}$ \\
\hline Triarylmethanes & Noimark [107] & 2016 & $\begin{array}{l}\text { Theoretical } \\
\text { and materials } \\
\text { lab }\end{array}$ & $700 \mathrm{~nm}$ & $\begin{array}{l}\text { Kills both Gram-positive and Gram-negative } \\
\text { bacteria }\end{array}$ \\
\hline Phyto-therapeutic agents & Nardini [108] & 2019 & Dental lab & $\begin{array}{l}405 \mathrm{~nm} \\
460 \mathrm{~nm} \\
660 \mathrm{~nm}\end{array}$ & $\begin{array}{l}\text { Significant reduction of plactonic and biofilm } \\
\text { manifestations of E. faecalis in Bovine dentin } \\
\text { samples }\end{array}$ \\
\hline Cyanines & Delaey [109] & 2000 & Biological lab & $545 \mathrm{~nm}-824 \mathrm{~nm}$ & High degree of photosensitisation in vitro \\
\hline Fullerenes & Tegos [110] & 2005 & chemical lab & Visible light & $\begin{array}{l}\text { Kills Gram-positive bacteria, Gram-negative } \\
\text { bacteria, and funghi }\end{array}$ \\
\hline Vitamin B derivatives & $\begin{array}{l}\text { Baier [111] } \\
\text { Maisch [112] }\end{array}$ & $\begin{array}{l}2006 \\
2014\end{array}$ & Biological lab & UV & Greatly reduces multi-resistant bacteria \\
\hline Curcumin & Qiong-Qiong Yang [113] & 2020 & Biological lab & $470 \mathrm{~nm}$ & $\begin{array}{l}\text { Destroyed Staphylococcus aureus and prevented } \\
\text { it's regrowth }\end{array}$ \\
\hline Curcumin & Qiong-Qiong Yang [113] & 2020 & Animal lab & $470 \mathrm{~nm}$ & $\begin{array}{l}\text { Reduced Streptococcus mutans in dental sam- } \\
\text { ples }\end{array}$ \\
\hline
\end{tabular}


minimal incubation period (15 min) were used by Morley and co-authors [63] in a Phase IIa placebo-controlled Randomised controlled trial (RCT). They demonstrated complete clearance of half (four out of eight) of the treated leg ulcers by 3 months, with less conclusive results on a cohort with diabetic foot ulcers (DFU's). A development of this DFU work [68] recommended PDT to target gram-positive cocci in cellulitis therapy. The surface area of leg ulcers was reduced by three in those receiving ten high-fluence treatments of ALA PDT, compared to a halving in size of placebo groups lesions [64].

As the total annual cost of diabetic foot ulcer complications in the UK is $£ 252$ million [65], the ability to eradicate a range of bacterial species across large areas and volumes of tissue is paramount. In the longer term, prevention of DFU's is desirable and a recent systematic review [66] identified bespoke orthotics, antifungal nail lacquer and elastic compression stockings as appropriate methods in those at risk. A 2017 International consensus statement on the treatment of DFU's [67] appealed for strategies appropriate to a resourcelimited setting. Daylight PDT depends only the availability of a characterised photosensitising ointment, opaque dressings and knowledge of the relationship between real-time solar irradiance and fluence $\left(\mathrm{J} / \mathrm{cm}^{2}\right)$ given a geographical location.

AMPS are cationic and combat infection through their direct microbicidal properties and/or by influencing the host's immune responses [68]. The former property targets the cytoplasmic membrane or the peptidoglycan cell wall both of which are robust structures that do not change easily meaning resistance does not develop. Identifying and harvesting naturally occurring AMPs is labour intensive, however, equipment and protocols have now been developed to synthesise them artificially, $[69,70]$ and peptide libraries of the increasing number of known organic and synthetic versions also emerging [71]. DRAMP 2.0 is perhaps the most detailed database which identifies just 76 AMPs in clinical use (less than $1 \%$ of the total) [72] and only seven AMPS with FDA approval [27]. These small numbers imply that both scientific and administrative constraints exist on the transition from the laboratory to clinical practice- and more research could be focused on these areas.

In vitro studies have demonstrated that commonly prescribed antidepressants Citalopram and Venlafaxine enhance the effect of antibiotics [73]. Moreover, Citalopram increased susceptibility of Cefixime-resistant Escherichia coli and Cloxacillin-resistant Pseudomonas aeruginosa when used alongside these antibiotics. Likewise, Venlafaxine increased the susceptibility of resistant $P$. aeruginosa to the same drugs. The underlying mechanism is thought to be blocking of de novo efflux pumps formed during the resistance process [73]. However, this does not apply to all SSRI
Table 2 Gradings used for the quality of evidence used for clinical recommendations

\begin{tabular}{|c|c|c|}
\hline Quality of Evidence & Symbol & Letter \\
\hline & & \\
\hline High & $\bigoplus \bigoplus \bigoplus \bigoplus$ & $\mathrm{A}$ \\
\hline Moderate & $\bigoplus \bigoplus \bigoplus \bigcirc$ & $\mathrm{B}$ \\
\hline Low & $\bigoplus \bigoplus \bigoplus \bigcirc$ & $\mathrm{C}$ \\
\hline Very Low & $\bigoplus \bigcirc \bigcirc$ & $\mathrm{D}$ \\
\hline
\end{tabular}

Table 3 Terminology and symbols used to communicate the strength of a clinical recommendation

\begin{tabular}{|l|l|l|l|}
\hline Strength of Recommendation & Symbol & Number & Letter \\
\hline & & & \\
\hline Strong for Intervention & & 1 & A \\
\hline Weak for Intervention & $?$ & 2 & B \\
\hline Weak against Intervention & $?$ & 2 & B \\
\hline Strong against Intervention & & 1 & A \\
\hline
\end{tabular}

and SNRI drugs; fluoxetine, has been shown to increase the mutation frequency of $E$. coli to a series of antibiotics [74]. There are many other drugs and supplements thought to inhibit the effect of antibiotics and ultimately exacerbate AMR [79] and consideration of these specific interactions during prescribing is a necessary step in antimicrobial stewardship.

The original 2002 European Guidelines for topical PDT [75] provided a review of its historical use, concluding that both coherent and non-coherent light sources were suitable and acknowledging 5-ALA as the most prevalent photosensitiser. It also highlighted the antimicrobial applications of PDT for acne and warts. By 2008 [76] Acne, warts and Cutaneous Leishmaniasis (CL) were given a B strength of recommendation for treatment with PDT, secondary to first-class evidence according to the GRADE system [77] (Tables 2, 3). In the 2012 revision [78] the only antimicrobial application assigned ' $A$ ' strength of recommendation given the highest quality of evidence was Acne. Cutibacterium acnes is a gram positive, anaerobic, slow-growing bacterium, and the resulting vesicles are one of the most common skin diseases. While there was no approved treatment protocol in the 2012 document, it was acknowledged that low drug concentrations, short incubation times and low blue light doses (13 J/ $\mathrm{cm}^{2}$ ) achieve short-term antimicrobial and immunomodulatory effects, while higher doses $\left(150 \mathrm{~J} / \mathrm{cm}^{2}\right)$ of red light also destroy sebaceous glands. Enhanced epidermal turnover is the likely effect of all PDT leading to reduced follicular obstruction and decreased sebum excretion [79]. Warts (refractory viral hand and foot warts, genital warts) and CL 
were also mentioned as they had top quality evidence with a 'B' strength of recommendation. For warts, ALA followed by a pulsed dye laser or LED source gave clearance rates of up to $100 \%$ [80]. In CL, ALA with red light illumination was found to be effective, with no relapses at 6 months [81]. Finally, the use of PDT for the fungal infection Onychomycosis was introduced cautiously.

In the 2019 update of the European guidelines for topical PDT [82], Acne, CL, Onychomycosis and refractory warts all achieved a B strength of recommendation given high-quality evidence. Similar outcomes for ALA-PDT and MAL-PDT were reported for acne, however, MAL had fewer side effects [83]. Blue and red-light illumination were reported to provide similar results, despite the earlier assertion that longer wavelengths (red) are more penetrating, providing permanent results. Daylight PDT was also successful for treating acne, when fractional laser-assisted [84]. For warts, evidence of excellent results using ALA was reported [85] with low recurrence rates relative to $\mathrm{CO} 2$ laser treatment [86]. New data for the Leishmania major and Leishmania tropica species causing CL revealed optimal results using multiple red-light PDT treatments with high fluences (up to $100 \mathrm{~J} / \mathrm{cm}^{2}$ ) [87], with repeat daylight PDT proving reasonably effective [88]. For Onychomycosis, methylene blue PDT was very effective, especially with prior abrasion of the nail with fluconazole [89].

The British Association of Dermatologists (BAD)/British Photodermatology Group (BPG) published their recommendations in 2018 based on the available evidence, as well as consensus and specialist experience [90]. The four pertinent recommendations of the British group were: (1) Consider PDT for CL, particularly in cosmetically sensitive sites; (2) Consider daylight PDT for CL, bearing in mind that several treatments may be required; (3) Consider PDT as a treatment option for recalcitrant viral warts; (4) Do not offer PDT as a treatment option for fungal infections. Notably, this guideline does not mention Acne in its recommendations, and it concurs with the contemporaneous European guideline on viral warts, and essentially for CL. Both documents align on the use of serial daylight PDT for CL and a less onerous method is also likely to be popular with patients.

The first-ever UK NICE clinical guideline on the management of Acne Vulgaris will be published in 2021 and lists topical medicines and antibiotics in various combinations as first and second-line treatments, with referral to a consultant dermatologist and the use of oral isotretinoin and prednisolone as third-line treatments [91]. There is a risk that the $C$. acnes and commensal microflora of patients using topical antibiotics, and their close contacts, will develop antibiotic resistance, however, concurrent use of topical retinoids or Benzoyl peroxide negate this [92, 93]. PDT is highlighted for consideration in adults with moderate to severe acne if other treatments are contraindicated, ineffective or poorly tolerated. Similarly, it is not contraindicated for children. Pertinently to this review, one of its recommendations for research is the investigation of light devices in the treatment of acne vulgaris and it's persistent scarring.

There are no active NICE guidelines on CL, Onychomycosis, warts, Leg ulcers (LU), or diabetic foot ulcers (DFU). However NICE technology appraisal of Urgostart dressings mentions their suitability for both types of ulcer [94] with antibiotics only necessary if the lesion becomes clinically infected. Offloading is the reduction, redistribution or removal of detrimental forces applied to the foot [95] and is a primary treatment for foot ulcers alongside control of ischaemia and wound debridement. Technology appraisal of Ambulight PDT for small non-melanoma skin cancer supports its use and highlights that the relatively low irradiance is less painful than conventional PDT [96]. While it is more expensive to implement, it would certainly have an antimicrobial application in circumstances where conventional PDT is unavailable and daylight PDT is inappropriate. Clinical trials would establish the optimum doses and treatment regimens for different types of ulcer (Table 4).

Table three ranks the outcome of PDT in Clinical Antimicrobial PDT studies. As this parameter was often reported qualitatively, I have shown how I converted each outcome into a percentage and acknowledge the subjectivity involved. It can be surmised that $100 \%$ eradication of warts and acne is possible, and very good results for leg ulcers is achievable. Porphyrin or very long incubation periods after ALA application were specifically beneficial for warts. In acne, the best results were achieved with ALA and a very small light fluence. Leg Ulcers responded to the combination of methylene blue and infrared light with standard fluence and incubation; but when the latter was reduced, results were poor. CL was consistently improved rather than resolved completely and this applied to a range of photosensitiser/ $\lambda$ combinations.

The overall results for aPDT are more variable than those seen for skin cancers [40, 43], where an average efficacy of $82 \%$ was found. Cancer research has a long and relatively well-funded history with more focus on the optimal technical combinations and so further methodological research in aPDT may yield improved clinical results. The variation in findings for aPDT is echoed by the subset of clinical applications unrelated to cancer or microbes ([45, 46, 48-50], table Ibbotson).

The long-term impact of the clinical guidelines discussed here and the broader WHO strategy for reducing antimicrobial resistance [97] can be monitored on antibiotic footprint. net and eucast.org. The former shows antibiotic use across countries and industries, and the latter lists minimum inhibitory concentrations (MICs) of a range of antibiotics for the eradication of a variety of microbes. Increasing MIC values for a specific drug-pathogen combination indicates that 
Table 4 Antimicrobial applications of PDT and their clinical efficacy

\begin{tabular}{|c|c|c|c|c|c|c|}
\hline References & Pathology & Photosensitiser & Light & Additional facilitation & Reported efficacy (\%) & $\begin{array}{l}\text { Estimated } \\
\text { efficacy } \\
(\%)\end{array}$ \\
\hline [104] & Viral warts & Porphyrin & Red & - & 100 & 100 \\
\hline [103] & Recalcitrant viral warts & ALA & Broadband visible & $\begin{array}{l}\text { Quadruple incubation } \\
\text { period }\end{array}$ & 100 & 100 \\
\hline [103] & Acne & ALA & Broadband visible & Small fluence & 100 & 100 \\
\hline$[103]$ & Acne & ALA & Red & Very small fluence & 100 & 100 \\
\hline 61 & Leg ulcers & Methylene blue & Infrared & - & 83 & 83 \\
\hline$[103]$ & Recalcitrant viral warts & ALA & Broadband visible & Large fluence & 75 & 75 \\
\hline [103] & Recalcitrant viral warts & ALA & Broadband visible & - & 73 & 73 \\
\hline $75 b$ & Warts & ALA & Broadband & - & 58 & 58 \\
\hline$[103]$ & Recalcitrant viral warts & ALA & Broadband visible & $\begin{array}{l}\text { Prior paring to blood } \\
\text { vessels, Large flu- } \\
\text { ence }\end{array}$ & 56 & 56 \\
\hline $75 \mathrm{c}$ & Warts & ALA & Broadband & - & 56 & 56 \\
\hline $62 \mathrm{a}$ & Leg ulcers & Methylene Blue & Infrared & $\begin{array}{l}\text { Reduced incubation } \\
\text { period }\end{array}$ & 50 & 50 \\
\hline [104] & Cutaneous leishmaniasis & Porphyrin & Red & - & $\begin{array}{l}\text { Reduced parasitic } \\
\text { load }\end{array}$ & 50 \\
\hline [104] & Cutaneous leishmaniasis & Phthalocyanine & Red & - & $\begin{array}{l}\text { Reduced parasitic } \\
\text { load }\end{array}$ & 50 \\
\hline [104] & Cutaneous leishmaniasis & Chlorine & Blue & - & $\begin{array}{l}\text { Reduced parasitic } \\
\text { load }\end{array}$ & 50 \\
\hline \multirow[t]{3}{*}{ [104] } & Acne & Porphyrin & Red & - & $\begin{array}{l}\text { Reduced number of } \\
\text { lesions }\end{array}$ & 50 \\
\hline & Acne & Chlorine & Red & - & $\begin{array}{l}\text { Reduced microbial } \\
\text { load }\end{array}$ & 50 \\
\hline & Acne & ALA & Broadband visible & Large fluence & Clinical improvement & 50 \\
\hline $75 \mathrm{a}$ & Acne & ALA & Red & - & All improved & 50 \\
\hline [103] & Recalcitrant viral warts & ALA & Red & - & 42 & 42 \\
\hline 63 & Cellulitis & ALA & Red & - & 40 & 40 \\
\hline [103] & Recalcitrant viral warts & ALA & Blue & - & 28 & 28 \\
\hline $62 b$ & Diabetic foot ulcers & Methylene blue & $810 \mathrm{~nm}$ & $\begin{array}{l}\text { Reduced incubation } \\
\text { period }\end{array}$ & Inconclusive & 0 \\
\hline
\end{tabular}

Typical technical parameters are a $4 \mathrm{~h}$ incubation period after photosensitiser application and a light fluence of $37 \mathrm{~J} / \mathrm{cm}^{2}$; significant variations from this are noted

resistance is developing over time and so maintenance may be the desirable outcome.

So, in conclusion, combinations of treatments for microbial infection will optimise outcomes in the future and more clinical trials are necessary to demonstrate the ideal mix and delivery methods of agents and illumination for specific conditions and patient cohorts. Nanotheranostics will be subject to broad clinical evaluation and may include PDT for antimicrobial indications. Reported uses of this emergent technology include: the delivery of AMPs [98] and antibiotics [31]; with adjunct illumination to modulate antibiotic function or monitor progress in bacterial eradication [12]; simultaneous PDT, PTT and bioluminescence [99]; the management of sepsis [100]. Conventional PDT will undoubtedly play a part given its large evidence base and existing healthcare facilities and infrastructure-It may be the only treatment necessary for some cases of Acne vulgaris and related scarring. Daylight PDT and the use of ambulatory devices could become more popular in regions where resources are limited, with a broader scope than just CL and Acne Vulgaris—subject to high-quality evidence. In theory, the resistance of microbes to antibiotics is reversible, and in practice it is possible that new resistance could at least be halted by the use of supplementary drugs. Antibiotics are therefore unlikely to become obsolete. 
Acknowledgements The author would like to thank Ms. Kari O'Neill, Mr. Robert Bolton, and Mr. Andrew Gardner for their support during a challenging period in the UK NHS, and Professor Lesley Rhodes for her comments on the manuscript.

Funding The author did not receive financial support from any organization for the submitted work.

Data availability As there was no data collected for this review, data cannot be made available.

Code availability There was no code written during this study, and so code cannot be made available.

\section{Declarations}

Conflict of interest The author has no conflicts of interest to disclose.

Ethical approval Ethics approval was not required as we did not recruit subjects to this review.

Consent to participate Consent to participate was not required as there were no subjects in this review.

Consent to publish Consent to publish was not required as there were no patients in this review.

\section{References}

1. Abbas, S. M., Doll, M., \& Stevens, M. P. (2018). Vertical versus horizontal infection control interventions. In G. Bearman, S. Munoz-Price, D. Morgan, \& R. Murthy (Eds.), Infection prevention. Cham: Springer. https://doi.org/10.1007/978-3-319-609805_18

2. Spikes, J. D. (1985). The historical development of ideas on applications of photosensitized reactions in the health sciences. In R. V. Bensasson, G. Jori, E. J. Land, \& T. G. Truscott (Eds.), Primary photo-processes in biology and medicine. Boston: Springer. https://doi.org/10.1007/978-1-4684-1224-6_12

3. Torabi, S., Joharchi, K., Kalhori, K. A. M., Sohrabi, M., \& Fekrazad, R. (2021). Evaluation of antimicrobial photodynamic therapy on wounds infected by Staphylococcus aureus in animal models. Photodiagnosis and Photodynamic Therapy. https://doi. org/10.1016/j.pdpdt.2020.102092

4. Kovács, K. (2019). Laser photodynamic therapy procedures. In C. J. Winkler (Ed.), Laser surgery in veterinary medicine. Hoboken: Wiley. https://doi.org/10.1002/9781119486053.ch16

5. Olarte, J., \& De la Torre, J. A. (1959). Resistance of Shigella flexneri to tetracyclines, chloramphenicol and streptomycin; a study of 131 freshly isolated strains. American Journal of Tropical Medicine and Hygiene, 8(3), 324-326. https://doi.org/10. 4269/ajtmh.1959.8.324

6. Cox, G., \& Wright, G. D. (2013). Intrinsic antibiotic resistance: Mechanisms, origins, challenges and solutions. International Journal of Medical Microbiology, 303(6-7), 287-292. https:// doi.org/10.1016/j.ijmm.2013.02.009

7. Guerin, E., Cambray, G., Sanchez-Alberola, N., Campoy, S., Erill, I., Da Re, S., Gonzalez-Zorn, B., Barbé, J., Ploy, M. C., \& Mazel, D. (2009). The SOS response controls integron recombination. Science, 324(5930), 1034. https://doi.org/10.1126/scien ce. 1172914
8. Guerin, E., Cambray, G., Da Re, S., Mazel, D., \& Ploy, M. C. (2010). Les antibiotiques induisent la capture de gènes de résistance par les bactéries [The SOS response controls antibiotic resistance by regulating the integrase of integrons]. Medicine Science (Paris), 26(1), 28-30. https://doi.org/10.1051/medsci/ 201026128

9. Lerminiaux, N. A., \& Cameron, A. D. S. (2019). Horizontal transfer of antibiotic resistance genes in clinical environments. Canadian Journal of Microbiology, 65(1), 34-44. https://doi.org/ 10.1139/cjm-2018-0275

10. Aminov, R. I., \& Mackie, R. I. (2007). Evolution and ecology of antibiotic resistance genes. FEMS Microbiology Letters, 271(2), 147-161. https://doi.org/10.1111/j.1574-6968.2007.00757.x

11. Mwangi, M. M., Wu, S. W., Zhou, Y., Sieradzki, K., de Lencastre, H., Richardson, P., Bruce, D., Rubin, E., Myers, E., Siggia, E. D., \& Tomasz, A. (2007). Tracking the in vivo evolution of multidrug resistance in Staphylococcus aureus by whole-genome sequencing. Proceedings of the National Academy of Sciences, 104(22), 9451-9456. https://doi.org/10.1073/pnas.0609839104

12. Smitten, K., Fairbanks, S., Robertson, C., de la Serna, J. B., Foster, S., \& Thomas, J. (2019). Ruthenium based antimicrobial theranostics-Using nanoscopy to identify therapeutic targets and resistance mechanisms in Staphylococcus aureus. Chemical Science. https://doi.org/10.1039/C9SC04710G

13. PHE. (2020). COVID-19: Infection prevention and control guidance June 2020. GW-1250.

14. PHE. (2021). COVID-19: Guidance for maintaining services within health and care settings. Infection prevention and control recommendations. GW-1659.

15. Villani, F. A., Aiuto, R., Paglia, L., \& Re, D. (2020). COVID-19 and dentistry: Prevention in dental practice, A literature review. International Journal of Environmental Research and Public Health, 17(12), 4609. https://doi.org/10.3390/ijerph17124609

16. Azuma, K., Yanagi, U., Kagi, N., Kim, H., Ogata, M., \& Hayashi, M. (2020). Environmental factors involved in SARS-CoV-2 transmission: Effect and role of indoor environmental quality in the strategy for COVID-19 infection control. Environmental Health Prevention Medicine, 25(1), 66. https://doi.org/10.1186/ s12199-020-00904-2

17. Hsu, J. (2020). How covid-19 is accelerating the threat of antimicrobial resistance. BMJ, 369, m1983. https://doi.org/10.1136/ bmj.m1983

18. Clancy, C. J., \& Nguyen, M. H. (2020). Coronavirus disease 2019, superinfections, and antimicrobial development: What can we expect? Clinical Infection Disease, 71(10), 2736-2743. https://doi.org/10.1093/cid/ciaa524

19. Davies, J., \& Davies, D. (2010). Origins and evolution of antibiotic resistance. Microbiology and Molecular Biology Reviews: MMBR, 74(3), 417-433. https://doi.org/10.1128/MMBR. 00016-10

20. Novickij, V., Zinkevičienè, A., Perminaitè, E., et al. (2018). Noninvasive nanosecond electroporation for biocontrol of surface infections: An in vivo study. Scientific Reports, 8, 14516. https:// doi.org/10.1038/s41598-018-32783-7

21. Lei, J., Sun, L., Huang, S., Zhu, C., Li, P., He, J., Mackey, V., Coy, D. H., \& He, Q. (2019). The antimicrobial peptides and their potential clinical applications. American Journal of Translational Research, 11(7), 3919-3931.

22. Abdel-kader, M. H. (2016). The journey of PDT throughout history: PDT from Pharos to present chapter. In H. Kostron \& T. Hasan (Eds.), Photodynamic medicine: From bench to clinic. Royal Society of Chemistry.

23. Huang, X., El-Sayed, I. H., Qian, W., \& El-Sayed, M. A. (2006). Cancer cell imaging and photothermal therapy in the near-infrared region by using gold nanorods. Journal of the American 
Chemical Society, 128(6), 2115-2120. https://doi.org/10.1021/ ja057254a

24. Vatansever, F., de Melo, W. C., Avci, P., Vecchio, D., Sadasivam, M., Gupta, A., Chandran, R., Karimi, M., Parizotto, N. A., Yin, R., Tegos, G. P., \& Hamblin, M. R. (2013). Antimicrobial strategies centered around reactive oxygen species-Bactericidal antibiotics, photodynamic therapy, and beyond. FEMS Microbiology Reviews, 37(6), 955-989. https://doi.org/10.1111/15746976.12026

25. Blaskovich, M. A. T., Kavanagh, A. M., Elliott, A. G., et al. (2021). The antimicrobial potential of cannabidiol. Communications Biology, 4, 7. https://doi.org/10.1038/s42003-020-01530-y

26. Steinstrasser, L., Lam, M. C., Jacobsen, F., Porporato, P. E., Chereddy, K. K., Becerikli, M., Stricker, I., Hancock, R. E., Lehnhardt, M., Sonveaux, P., Préat, V., \& Vandermeulen, G. (2014). Skin electroporation of a plasmid encoding hCAP-18/ LL-37 host defense peptide promotes wound healing. Molecular therapy: The journal of the American Society of Gene Therapy, 22(4), 734-742. https://doi.org/10.1038/mt.2013.258

27. Chen, C. H., \& Lu, T. K. (2020). Development and challenges of antimicrobial peptides for therapeutic applications. Antibiotics, 9(1), 24. https://doi.org/10.3390/antibiotics9010024

28. Klausen, M., Ucuncu, M., \& Bradley, M. (2020). Design of photosensitizing agents for targeted antimicrobial photodynamic therapy. Molecules, 25(22), 5239. https://doi.org/10.3390/molec ules25225239

29. Xie, S., Manuguri, S., Proietti, G., Romson, J., Fu, Y., Inge, A. K., Wu, B., Zhang, Y., Häll, D., Ramström, O., \& Yan, M. (2017). Design and synthesis of theranostic antibiotic nanodrugs that display enhanced antibacterial activity and luminescence. Proceedings of the National Academy of Sciences of the United States of America, 114(32), 8464-8469. https://doi.org/10.1073/ pnas. 1708556114

30. Bullous, A. J. (2011). Photosensitiser-antibody conjugates for photodynamic therapy. Photochemical and Photobiological Sciences, 10, 721-750. https://doi.org/10.1039/C0PP00266F

31. Lehar, S., Pillow, T., Xu, M., et al. (2015). Novel antibody-antibiotic conjugate eliminates intracellular S. aureus. Nature, 527, 323-328. https://doi.org/10.1038/nature16057

32. Le, H., Arnoult, C., Dé, E., Schapman, D., Galas, L., Cerf, D. L., \& Karakasyan, C. (2021). Antibody-conjugated nanocarriers for targeted antibiotic delivery: Application in the treatment of bacterial biofilms. Biomacromolecules. https://doi.org/10.1021/ acs.biomac.1c00082

33. Huang, X., Neretina, S., \& El-Sayed, M. A. (2009). Gold nanorods: From synthesis and properties to biological and biomedical applications. Advanced Materials, 21(48), 4880-4910.

34. Choi, S. K. (2020). Photo activation strategies for therapeutic release in nanodelivery systems. Advanced Therapeutics. https:// doi.org/10.1002/adtp.202000117

35. Mammen, M., Choi, S. K., \& Whitesides, G. M. (1998). Polyvalent interactions in biological systems: Implications for design and use of multivalent ligands and inhibitors. Angewandte Chemie (International ed in English), 37(20), 2754-2794. https://doi. org/10.1002/(SICI)1521-3773(19981102)37:20<2754::AIDAN IE2754>3.0.CO;2-3.

36. Selvan, S. T., \& Narayanan, K. (2016). Introduction to nanotheranostics (pp. 1-6). Singapore: Introduction to nanotheranostics. Springer. https://doi.org/10.1007/978-981-10-1008-8

37. Kirubakaran, N., Chandrika, M., \& Reeta Vijaya Rani, K. (2015). Iontophoresis: Controlled transdermal drug delivery system. IJPSR, 6(8), 3174-3185. https://doi.org/10.13040/IJPSR. 0975-8232

38. Rhodes, L. E., Tsoukas, M. M., Anderson, R. R., \& Kollias, N. (1997). Iontophoretic delivery of ALA provides a quantitative model for ALA pharmacokinetics and PpIX phototoxicity in human skin. Journal of Investigative Dermatology, 108(1), 87-91. https://doi.org/10.1111/1523-1747.ep12285644

39. Lepak, L. V. (2007). Chapter 7-Localized inflammation. In M. Cameron \& L. G. Monroe (Eds.), Physical rehabilitation (pp. 117-139). Philadelphia: W.B. Saunders. https://doi.org/10.1016/ B978-072160361-2.50010-7

40. Mizutani, K., Watanabe, D., Akita, Y., Akimoto, M., Tamada, Y., \& Matsumoto, Y. (2009). Photodynamic therapy using directcurrent pulsed iontophoresis for 5-aminolevulinic acid application. Photodermatology, Photoimmunology and Biomedicine. https://doi.org/10.1111/j.1600-0781.2009.00456.x

41. Tan, G. Z., Orndorff, P. E., \& Shirwaiker, R. A. (2019). The ion delivery manner influences the antimicrobial efficacy of silver oligodynamic iontophoresis. Journal of Medical and Biological Engineering, 39, 622-631. https://doi.org/10.1007/ s40846-018-0447-1

42. Fish, R. M., \& Geddes, L. A. (2009). Conduction of electrical current to and through the human body: A review. Eplasty, 9, e44.

43. Cohen, D. K., \& Lee, P. K. (2016). Photodynamic therapy for non-melanoma skin cancers. Cancers, 8(10), 90. https://doi.org/ 10.3390/cancers8100090

44. Mackay, A. M., Brown, M. C., Hagan, R. P., et al. (2007). Deficits in the electroretinogram in neovascular age-related macular degeneration and changes during photodynamic therapy. Documenta Ophthalmologica, 115, 69-76. https://doi.org/10.1007/ s10633-007-9056-y

45. Treatment of Age-Related Macular Degeneration with Photodynamic Therapy (TAP) Study Group. (1999). Photodynamic therapy of subfoveal choroidal neovascularization in age-related macular degeneration with verteporfin. One-year results of 2 randomized clinical trials-TAP report 1. Archives Ophthalmology, 117, 1329-1345.

46. Tang, G., Hyman, S., John, H., Schneider, M. D., Jr., Steven, L., \& Giannotta, M. D. (1993). Application of photodynamic therapy to the treatment of atherosclerotic plaques. Neurosurgery, 32(3), 438-443. https://doi.org/10.1227/00006123-199303000-00016

47. Gallardo-Villagrán, M., Leger, D. Y., Liagre, B., \& Therrien, B. (2019). Photosensitizers used in the photodynamic therapy of rheumatoid arthritis. International Journal of Molecular Sciences, 20(13), 3339. https://doi.org/10.3390/ijms20133339

48. Barr, H. (2000). Barrett's esophagus: Treatment with 5-aminolevulinic acid photodynamic therapy. Gastrointestinal Endoscopy Clinics of North America, 10(3), 421-437. https://doi.org/10. 1016/S1052-5157(18)30114-4

49. Boehncke, W. H. (2001). Chapter 16 Topical photodynamic therapy for psoriasis. In P. Calzavara-Pinton, R. M. Szeimies, \& B. Ortel (Eds.), Comprehensive series in photosciences (Vol. 2, pp. 259-270). Oxford: Elsevier. https://doi.org/10.1016/S1568461X(01)80120-4

50. Jenkins, M. P., Buonaccorsi, G. A., Raphael, M., Nyamekye, I., McEwan, J. R., Bown, S. G., \& Bishop, C. C. R. (1999). Clinical study of adjuvant photodynamic therapy to reduce restenosis following femoral angioplasty. British Journal of Surgery, 86, 1258-1263. https://doi.org/10.1046/j.1365-2168.1999.01247.x

51. Hamblin, M. R., \& Hasan, T. (2004). Photodynamic therapy: A new antimicrobial approach to infectious disease? Photochemical and Photobiological Sciences: Official Journal of the European Photochemistry Association and the European Society for Photobiology, 3(5), 436-450. https://doi.org/10.1039/b311900a

52. Hamblin, M. R. (2016). Antimicrobial photodynamic inactivation: A bright new technique to kill resistant microbes. Current Opinion in Microbiology, 33, 67-73. https://doi.org/10.1016/j. mib.2016.06.008 
53. Ivanova, V. A., Verenikina, E. V., Nikitina, V. P., Zhenilo, O. E., Kruze, P. A., Nikitin, I. S., \& Kit, O. I. (2020). Photodynamic therapy for preinvasive cervical cancer. Journal of Clinical Oncology, 38(15 suppl), 6035-6035.

54. Nesi-Reis, V., Lera-Nonose, D., Oyama, J., Silva-Lalucci, M., Demarchi, I. G., Aristides, S., Teixeira, J., Silveira, T., \& Lonardoni, M. (2018). Contribution of photodynamic therapy in wound healing. Photodiagnosis and Photodynamic Therapy, 21, 294305. https://doi.org/10.1016/j.pdpdt.2017.12.015

55. Robertson, C. A., Evans, D. H., \& Abrahamse, H. (2009). Photodynamic therapy (PDT): A short review on cellular mechanisms and cancer research applications for PDT. Journal of Photochemistry and Photobiology B: Biology, 96(1), 1-8. https://doi.org/10. 1016/j.jphotobiol.2009.04.001

56. Richter, A. M., Jain, A. K., Canaan, A. J., Waterfield, E., Sternberg, E., \& Levy, J. G. (1992). Photosensitizing efficiency of two regioisomers of the benzoporphyrin derivative monoacid ring a (BPD-MA). Biochemical Pharmacology, 43(11), 2349-2358. https://doi.org/10.1016/0006-2952(92)90313-8

57. Yanka, D., et al. (2021). Photodynamic optimization by combination of xanthene dyes on different forms of Streptococcus mutans: An in vitro study. Photodiagnosis and Photodynamic Therapy, 33, 102191.

58. Aaron, J. J., Gaye Seye, M. D., Trajkovska, S., \& Motohashi, N. (2008). Bioactive phenothiazines and benzo[a]phenothiazines: Spectroscopic studies, and biological and biomedical properties and applications. In N. Motohashi (Ed.), Bioactive heterocycles VII. Topics in heterocyclic chemistry. (Vol. 16). Springer. https:// doi.org/10.1007/7081_2008_125

59. Kasimova, K. R., Sadasivam, M., Landi, G., Sarna, T., \& Hamblin, M. R. (2014). Potentiation of photoinactivation of Grampositive and Gram-negative bacteria mediated by six phenothiazinium dyes by addition of azide ion. Photochemical and Photobiological Sciences: Official Journal of the European Photochemistry Association and the European Society for Photobiology, 13(11), 1541-1548. https://doi.org/10.1039/c4pp00021h

60. Yin, R., Wang, M., Huang, Y. Y., Landi, G., Vecchio, D., Chiang, L. Y., \& Hamblin, M. R. (2015). Antimicrobial photodynamic inactivation with decacationic functionalized fullerenes: Oxygen independent photokilling in presence of azide and new mechanistic insights. Free Radical Biology and Medicine, 79, 14-27. https://doi.org/10.1016/j.freeradbiomed.2014.10.514

61. Wu, H., Zeng, F., Zhang, H., Xu, J., Qiu, J., \& Wu, S. (2016). A nanosystem capable of releasing a photosensitizer bioprecursor under two-photon irradiation for photodynamic therapy. Advancement of Science, 3, 1500254. https://doi.org/10.1002/ advs.201500254

62. Bennewitz, A., Prinz, M., \& Wollina, U. (2013). Photodynamic therapy to improve wound healing in acute and chronic wounds: Tricylic dye combined with low level $810 \mathrm{~nm}$ diode laser irradiation. Kosmetische Medizin, 34, 208-215.

63. Morley, S., et al. (2013). Phase IIa randomized, placebo-controlled study of antimicrobial photodynamic therapy in bacterially colonized, chronic leg ulcers and diabetic foot ulcers: A new approach to antimicrobial therapy. British Journal of Dermatology, 168(3), 617-624. https://doi.org/10.1111/bjd.12098

64. Krupka, M., Bozek, A., Bartusik-Aebisher, D., Cieslar, G., \& Kawczyk-Krupka, A. (2021). Photodynamic therapy for the treatment of infected leg ulcers-A pilot study. Antibiotics, 10, 506. https://doi.org/10.3390/antibiotics10050506

65. Gordois, A., Scuffham, P., Shearer, A., Oglesby, A., \& Tobian, J. A. (2003). The health care costs of diabetic peripheral neuropathy in the US. Diabetes Care, 26(6), 1790-1795. https://doi.org/ 10.2337/diacare.26.6.1790

66. Crawford, F., Nicolson, D. J., Amanna, A. E., et al. (2020). Preventing foot ulceration in diabetes: Systematic review and meta-analyses of RCT data. Diabetologia, 63, 49-64. https://doi. org/10.1007/s00125-019-05020-7

67. Karabanow, A. B., Zaimi, I., Suarez, L. B., Iafrati, M. D., \& Allison, G. M. (2021). An analysis of guideline consensus for the prevention, diagnosis and management of diabetic foot ulcers. Journal of the American Podiatric Medical Association. https:// doi.org/10.7547/19-175

68. Mookherjee, N., Anderson, M. A., Haagsman, H. P., et al. (2020). Antimicrobial host defence peptides: Functions and clinical potential. Nature Reviews Drug Discovery, 19, 311-332. https:// doi.org/10.1038/s41573-019-0058-8

69. Bormann, N., Koliszak, A., Kasper, S., Schoen, L., Hilpert, K., Volkmer, R., Kikhney, J., \& Wildemann, B. (2017). A short artificial antimicrobial peptide shows potential to prevent or treat bone infections. Scientific Reports, 7(1), 1506. https://doi.org/ 10.1038/s41598-017-01698-0

70. Bopari, J. K., et al. (2020). Mini review on antimicrobial peptides, sources, mechanism and recent applications. Protein and Peptide Letters, 27(1), 4-16. https://doi.org/10.2174/0929866526 666190822165812

71. Ashby, M., Petkova, A., Gani, J., Mikut, R., \& Hilpert, K. (2017). Use of peptide libraries for identification and optimization of novel antimicrobial peptides. Current Topics in Medicinal Chemistry, 17(5), 537-553. https://doi.org/10.2174/156802661666616 0713125555

72. Kang, X., Dong, F., Shi, C., Liu, S., Sun, J., Chen, J., Li, H., Xu, H., Lao, X., \& Zheng, H. (2019). DRAMP 2.0, an updated data repository of antimicrobial peptides. Scientific Data, 6(1), 148. https://doi.org/10.1038/s41597-019-0154-y

73. Ayaz, M., Subhan, F., Ahmed, J., Khan, A., Ullah, F., Sadiq, A., Syed, N.-i-H., Ullah, I., \& Hussain, S. (2015). Citalopram and venlafaxine differentially augments antimicrobial properties of antibiotics. Acta Poloniae Pharmaceutica, 72, 1269-1278.

74. Jin, M., Lu, J., Chen, Z., Nguyen, S. H., Mao, L., Li, J., Yuan, Z., \& Guo, J. (2018). Antidepressant fluoxetine induces multiple antibiotics resistance in Escherichia coli via ROS-mediated mutagenesis. Environment International, 120, 421-430. https:// doi.org/10.1016/j.envint.2018.07.046

75. Morton, C. A., Brown, S. B., Collins, S., Ibbotson, S., Jenkinson, H., Kurwa, H., Langmack, K., McKenna, K., Moseley, H., Pearse, A. D., Stringer, M., Taylor, D. K., Wong, G., \& Rhodes, L. E. (2002). Guidelines for topical photodynamic therapy: Report of a workshop of the British Photodermatology Group. The British Journal of Dermatology, 146(4), 552-567.

76. Morton, C. A., McKenna, K. E., Rhodes, L. E., \& British Association of Dermatologists Therapy Guidelines and Audit Subcommittee and the British Photodermatology Group. (2008). Guidelines for topical photodynamic therapy: Update. The British Journal of Dermatology, 159(6), 1245-1266. https://doi.org/ 10.1111/j.1365-2133.2008.08882.x

77. Aguayo-Albasini, J. L., Flores-Pastor, B., \& Soria-Aledo, V. (2014). Sistema GRADE: Clasificación de la calidad de la evidencia y graduación de la fuerza de la recomendación n. Cirugía Española, 92, 82-88.

78. Morton, C. A., Szeimies, R.-M., Sidoroff, A., \& Braathen, L. R. (2012). European guidelines for topical photodynamic therapy part 2: Emerging indications-Field cancerization, photorejuvenation and inflammatory/infective dermatoses. Journal of the European Academy of Dermatology and Venereology: JEADV. https://doi.org/10.1111/jdv.12026

79. Sakamoto, F. H., Lopes, J. D., \& Anderson, R. R. (2010). Photodynamic therapy for acne vulgaris: a critical review from basics to clinical practice: Part I. Acne vulgaris: When and why consider photodynamic therapy? Journal of the American Academy of Dermatology, 63(2), 183-194. https://doi.org/10.1016/j.jaad. 2009.09.056 
80. Smucler, R., \& Jatsová, E. (2005). Comparative study of aminolevulic acid photodynamic therapy plus pulsed dye laser versus pulsed dye laser alone in treatment of viral warts. Photomedicine and Laser Surgery, 23, 202-205. https://doi.org/10.1089/pho. 2005.23.202

81. Enk, C. D., Fritsch, C., Jonas, F., Nasereddin, A., Ingber, A., Jaffe, C. L., \& Ruzicka, T. (2003). Treatment of cutaneous leishmaniasis with photodynamic therapy. Archives of Dermatology, 139(4), 432-434. https://doi.org/10.1001/archderm.139.4.432

82. Morton, C., et al. (2019). European Dermatology Forum guidelines on topical photodynamic therapy 2019 Part 2: Emerging indications-Field cancerization, photorejuvenation and inflammatory/infective dermatoses. Journal of the European Academy of Dermatology and Venereology: JEADV. https://doi.org/10. $1111 /$ jdv.16044

83. Wiegell, S. R., \& Wulf, H. C. (2006). Photodynamic therapy of acne vulgaris using 5-aminolevulinic acid versus methyl aminolevulinate. Journal of the American Academy of Dermatology, 54(4), 647-651. https://doi.org/10.1016/j.jaad.2005.12.033

84. Kim, T. I., Ahn, H.-J., Kang, I. H., Jeong, K.-H., Kim, N. I., \& Shin, M. K. (2017). Nonablative fractional laser-assisted daylight photodynamic therapy with topical methyl aminolevulinate for moderate to severe facial acne vulgaris: Results of a randomized and comparative study. Photodermatology, Photoimmunology and Photomedicine, 33, 253-259. https://doi.org/10.1111/phpp. 12312

85. Wang, Y. S., Tay, Y. K., Kwok, C., \& Tan, E. (2007). Photodynamic therapy with $20 \%$ aminolevulinic acid for the treatment of recalcitrant viral warts in an Asian population. International Journal of Dermatology, 46, 1180-1184. https://doi.org/10. 1111/j.1365-4632.2007.03210.x

86. Chen, K., Chang, B., Ju, M., Zhang, X., \& Gu, H. (2007). Comparative study of photodynamic therapy vs. $\mathrm{CO}_{2}$ laser vaporization in treatment of condylomata acuminata, a randomized clinical trial. British Journal of Dermatology, 156, 516-520. https:// doi.org/10.1111/j.1365-2133.2006.07648.x

87. Sainz-Gaspar, L., Rosón, E., Llovo, J., \& Vázquez-Veiga, H. (2019). Photodynamic therapy in the treatment of cutaneous leishmaniasis. Terapia fotodinámica en el tratamiento de la leishmaniasis cutánea. Actas Dermo-Sifiliograficas, 110(3), 249-251. https://doi.org/10.1016/j.ad.2018.02.018

88. Enk, C., Nasereddin, A., Alper, R., Dan-Goor, M., Jaffe, C., \& Wulf, H. (2015). Cutaneous leishmaniasis responds to daylightactivated photodynamic therapy: Proof of concept for a novel selfadministered therapeutic modality. British Journal of Dermatology, 172, 1364-1370. https://doi.org/10.1111/bjd.13490

89. Souza, L. W., Figueiredo, S., Trancoso, S. V., Botelho, A. C., \& de Carvalho. (2014). Distal and lateral toenail onychomycosis caused by Trichophyton rubrum: Treatment with photodynamic therapy based on methylene blue dye. Anais Brasileiros de Dermatologia, 89(1), 184-186. https://doi.org/10.1590/abd18064841.20142197

90. Wong, T., Morton, C., Collier, N., Haylett, A., Ibbotson, S., McKenna, K., Mallipeddi, R., Moseley, H., Seukeran, D., Rhodes, L., Ward, K., Mohd Mustapa, M., \& Exton, L. (2019). British Association of Dermatologists and British Photodermatology Group guidelines for topical photodynamic therapy 2018. British Journal of Dermatology, 180, 730-739. https://doi.org/10. 1111/bjd.17309

91. NICE guideline Acne Vulgaris (pending)

92. Eady, E. A., Bojar, R. A., Jones, C. E., Cove, J. H., Holland, K. T., \& Cunliffe, W. J. (1996). The effects of acne treatment with a combination of benzoyl peroxide and erythromycin on skin carriage of erythromycin resistant propionibacteria. British Journal of Dermatology, 134, 107-113. https://doi.org/10.1046/j.13652133.1996.d01-733.x
93. Walsh, T. R., Efthimiou, J., \& Dréno, B. (2016). Systematic review of antibiotic resistance in acne: An increasing topical and oral threat. The Lancet Infectious diseases, 16(3), e23-e33. https://doi.org/10.1016/S1473-3099(15)00527-7

94. NICE MTG 2019 Urgostart dressings. https://www.nice.org.uk/ guidance $/ \mathrm{mtg} 42$

95. Baker, N., \& Osman, I. (2016). The principles and practicalities of offloading diabetic foot ulcers. The Diabetic Foot Journal, 19(4), 172-181.

96. Ambulight PDT for the treatment of non-melanoma skin cancer. https://www.nice.org.uk/guidance/mtg6

97. WHO. World Action Plan on Antimicrobial Resistance. 2015. https:// WHA68/2015/REC/1, Annex 3

98. Mohid, S. A., \& Bhunia, A. (2020). Combining antimicrobial peptides with nanotechnology: An emerging field in theranostics. Current Protein and Peptide Science, 21(4), 413-428. https://doi. org/10.2174/1389203721666191231111634

99. Chitgupi, U., Qin, Y., \& Lovell, J. F. (2017). Targeted nanomaterials for phototherapy. Nanotheranostics, 1(1), 38-58. https:// doi.org/10.7150/ntno.17694

100. Jagtap, P., Sritharan, V., \& Gupta, S. (2017). Nanotheranostic approaches for management of bloodstream bacterial infections. Nanomedicine: Nanotechnology, Biology, and Medicine, 13(1), 329-341. https://doi.org/10.1016/j.nano.2016.09.005

101. Merchat, M., Spikes, J. D., Bertoloni, G., \& Jori, G. (1996). Studies on the mechanism of bacteria photosensitization by mesosubstituted cationic porphyrins. Journal of Photochemistry and Photobiology B, Biology, 35(3), 149-157.

102. Ng, D. K. (2014). Phthalocyanine-based photosensitizers: More efficient photodynamic therapy? Future Medicinal Chemistry, 6(18), 1991-1993.

103. Ibbotson, S. H. (2002). Topical 5-aminolaevulinic acid photodynamic therapy for the treatment of skin conditions other than non-melanoma skin cancer. The British Journal of Dermatology, 146(2), 178-188.

104. De Annunzio, S. R., Costa, N., Mezzina, R. D., Graminha, M., \& Fontana, C. R. (2019). Chlorin, phthalocyanine, and porphyrin types derivatives in phototreatment of cutaneous manifestations: A review. International Journal of Molecular Sciences, 20(16), 3861.

105. Yin, R., \& Hamblin, M. R. (2015). Antimicrobial photosensitizers: Drug discovery under the spotlight. Current Medicinal Chemistry, 22(18), 2159-2185.

106. Wilson, M., \& Mia, N. (1993). Sensitisation of Candida albicans to killing by low-power laser light. Journal of Oral Pathology and Medicine: Official publication of the International Association of Oral Pathologists and the American Academy of Oral Pathology, 22(8), 354-357. https://doi.org/10.1111/j.1600-0714. 1993.tb01088.x

107. Noimark, S., Salvadori, E., Gómez-Bombarelli, R., MacRobert, A. J., Parkin, I. P., \& Kay, C. W. (2016). Comparative study of singlet oxygen production by photosensitiser dyes encapsulated in silicone: Towards rational design of anti-microbial surfaces. Physical Chemistry Chemical Physics: PCCP, 18(40), 28101-28109.

108. Nardini, E. F., Almeida, T. S., Yoshimura, T. M., Ribeiro, M. S., Cardoso, R. J., \& Garcez, A. S. (2019). The potential of commercially available phytotherapeutic compounds as new photosensitizers for dental antimicrobial PDT: A photochemical and photobiological in vitro study. Photodiagnosis and Photodynamic Therapy, 27, 248-254.

109. Delaey, E., van Laar, F., De Vos, D., Kamuhabwa, A., Jacobs, P., $\&$ de Witte, P. (2000). A comparative study of the photosensitizing characteristics of some cyanine dyes. Journal of Photochemistry and Photobiology B: Biology, 55(1), 27-36. 
110. Tegos, G. P., Demidova, T. N., Arcila-Lopez, D., Lee, H., Wharton, T., Gali, H., et al. (2005). Cationic fullerenes are effective and selective antimicrobial photosensitizers. Chem Biol, 12(10), 1127-1135. https://doi.org/10.1016/j.chembiol.2005.08.014

111. Baier, J., Maisch, T., Maier, M., Engel, E., Landthaler, M., \& Bäumler, W. (2006). Singlet oxygen generation by UVA light exposure of endogenous photosensitizers. Biophys J, 91(4), 1452-1459. https://doi.org/10.1529/biophysj.106.082388.

112. Maisch, T., Eichner, A., Späth, A., Gollmer, A., König, B., Regensburger, J., et al. (2014). Fast and effective photodynamic inactivation of multiresistant bacteria by cationic riboflavin

\section{Authors and Affiliations}

\section{Alison M. Mackay ${ }^{1,2,3}$}

1 Division of Musculoskeletal and Dermatological Sciences, University of Manchester, Manchester, UK

2 Clinical Engineering, Salford Royal Foundation Trust, Salford, UK derivatives. PLoS One, 9(12), e111792. https://doi.org/10.1371/ journal.pone.0111792.

113. Yang, Q. Q., Farha, A. K., Kim, G., Gul, K., Gan, R. Y., \& Corke, H. (2020). Antimicrobial and anticancer applications and related mechanisms of curcumin-mediated photodynamic treatments. Trends in Food Science and Technology, 97, 341-354. https:// doi.org/10.1016/j.tifs.2020.01.023
3 Photobiology, Dermatology Centre, Salford Royal Foundation Trust, Salford, UK 